\title{
Vegetative Propagation of Schizachyrium tenerum (Poaceae) Under Different Substrates and Environments
}

\author{
Letícia Sena ${ }^{1}$ (]) \\ Thaise de O. Bahia ${ }^{2}$ (1) \\ Geraldo Wilson Fernandes ${ }^{3}$ (D)
}

\begin{abstract}
The Cerrado (Brazilian Savanna) biome suffers intense degradation due to several anthropic activities and its recovery is extremely important for the restoration of environmental quality. Therefore, the present study tested the survival and growth of seedlings of the grass Schizachyrium tenerum produced by the division of clumps. The experiment was carried out in a greenhouse using Reddish Oxisol, dystrophic of "cerrado sensu stricto" and Litholic Neosol dystrophic of quartzitic rupestrian grassland with and without the addition of limestone and NPK. Survival of S. tenerum was also compared between being grown in a greenhouse and directly in the field in full sun. Seedlings of $S$. tenerum had greater survival, total growth, number of tillers and accumulation of biomass when cultivated in Reddish Oxisol and Reddish Oxisol with limestone added than in the other treatments. Seedling survival was three times greater when grown in a greenhouse than in full sun.
\end{abstract}

Keywords: Cerrado, grasses, seedlings, restoration ecology, rupestrian grassland.

\section{INTRODUCTION}

Savanna and grassland vegetation types in Brazil, such as "cerrado sensu stricto" and rupestrian grassland (Campo Rupestre) are subject to constant degradation by human activities including agriculture and livestock monocultures (Klink \& Machado, 2005), mining (Le stradic et al., 2015a) and road construction (Barbosa et al., 2010), among others, which have been intensifying in recent decades (e.g., Klink \& Machado, 2005). Cerrado and grassland areas are dominated by herbaceous strata, mainly grasses (Haridassan, 2000; Viana \& Lombardi, 2007; Messias et al., 2012; Le Stradic et al., 2015a). Almost 400 species of native grasses have been described for "cerrado stricto sensu" (Mendonça et al., 2008) and 340 for rupestrian grassland (Viana \& Filgueiras, 2008). Grasses are widely distributed and occur in different environments, even in those where there are shallow soils with low fertility and little water retention (Messias et al., 2013), and they can easily colonize degraded environments (Jacobi et al., 2008). Due to processes of degradation, extensive areas of "Cerrado" currently require restoration (Cava et al., 2016). However, the erroneous practice of planting tree species in grassy environments has been recurrent, with great damage to ecosystems (Overbeck et al., 2013; Fernandes et al., 2016a). The introduction of trees in environments naturally dominated by herbaceous and shrubby plants alters the local biota and the hydrological regime and reduces ecosystem services (Fernandes \& Barbosa, 2013; Fernandes et al., 2016a). In addition, exotic grass species are commonly used in areas that require rapid soil coverage, disregarding the great diversity of native species (Durigan et al., 2013). The environmental damage resulting from planting of exotic grasses includes biological invasions, impediment of the establishment of native species and changes in the process of ecological succession, in addition to favoring the occurrence of severe fires due to the accumulation of above ground biomass (Simberloff, 2003; Martins et al., 2007; Figueiredo et al., 2012).

Among the most used forms of grass planting is direct sowing. However, the seeds of many native species have low viability and germination, making it difficult to use this

${ }^{1}$ Universidade Estadual de Montes Claros, Centro de Ciências Biológicas e da Saúde, Montes Claros, MG, Brasil.

${ }^{2}$ Universidade Federal de Ouro Preto, Departamento de Biodiversidade, Evolução e Meio Ambiente (DEBIO), Ouro Preto, MG, Brasil.

${ }^{3}$ Universidade Federal de Minas Gerais, Departamento de Genética, Ecologia \& Evolução, Belo Horizonte, MG, Brasil. 
technique (Carmona et al., 1999; Figueiredo et al., 2012; Le Stradic et al., 2015b). A promising and still poorly studied alternative is the method of vegetative propagation by clump division (Fernandes et al., 2016b; Santos, 2017; Figueiredo et al., 2018). The production of grasses on a large scale requires knowledge about the needs and physiological restrictions of each species, ideal substrate for planting, need for irrigation and climate tolerance. In general, soils in grassland areas of "Cerrado" and rupestrian grassland possess low concentrations of nutrients, while the process of liming and fertilizing can contribute to their productivity (Haridasan et al., 1997). However, in order to demonstrate these soil enrichment effects on the development of plants already adapted to nutritionally poor soils, each species needs to be investigated individually (Haridasan, 2000).

In view of the need to produce native grasses for environmental restoration, the present work aimed to test the performance of the species Schizachyrium tenerum Nees cultivated using the clump division (tillering) technique and different substrates in different environments (i.e., greenhouse and directly in the field). Thus, we hypothesized that: (I) S. tenerum will have higher survival and growth rates when grown on substrates with greater availability of nutrients (Haridasan et al., 1997) and that are slightly acidic pH (between 5 and 7), as well soil typical of the natural environments where the species occurs; and (II) survival of S. tenerum seedlings will be greater when grown in a greenhouse compared to direct cultivation in the field where the environmental conditions of solar radiation and humidity vary widely and represent strong environmental filters for adaptation and initial growth.

\section{MATERIAL AND METHODS}

\subsection{Study area}

The study was conducted at Reserva Vellozia $\left(19^{\circ} 16^{\prime} 45.7^{\prime \prime} \mathrm{S}\right.$, $\left.43^{\circ} 35^{\prime} 27.8^{\prime \prime} \mathrm{W}\right)$ located in Serra do Espinhaço, state of Minas Gerais, Brazil. The area is under the dominion of the "Cerrado" biome and is in the rupestrian grassland vegetation type. Fragments of "cerrado sensu stricto" can also be found in the grassland matrix (Almeida et al., 2017). Rupestrian grassland is characterized by predominantly sclerophilous and perennial vegetation on quartzitic-sandstone substrate (Giuliette et al., 1997; Fernandes et al., 2016b). The climate of the region presents mild summers and well-defined dry seasons (May to September), with an average annual temperature of $21.2^{\circ} \mathrm{C}$ and mean precipitation of $1622 \mathrm{~mm}$ (Fernandes et al., 2016b). The local climate is classified as mesothermic (Cwb), according to the classification of Köppen, which is characterized by dry winters and wet summers.

\subsection{Study species}

The grass $S$. tenerum was chosen due to the possibility for vegetative propagation facilitated by its physical and physiological characteristics, besides being quite abundant at the study site. Its growth is cespitose, that is, it forms typical clumps, which facilities its division into tillers. The species is distributed throughout Brazil in several biomes, such as "Cerrado", Atlantic Forest and Pampas, with high frequencies of occurrence in both natural and anthropized environments (Boldrini et al., 1998; Guimarães et al., 2002; Messias et al., 2012; Teixeira \& Lemos-Filho, 2013). The wide distribution of this species is important both to facilitate it use in restoration, as well as to validate and use this technique in other areas. In addition, S. tenerum is also resistant to fire (Filgueiras,1992), increasing its importance in the resilience of "Cerrado" and rupestrian grassland.

\subsection{Substrate preparation}

To assess the survival and growth of S. tenerum, six substrates were prepared with soil form quartzitic rupestrian grassland classified as Litholic Neosol (USDA, 1999; called in Portuguese Neossolo Litolítico - EMBRAPA, 2018) and "cerrado stricto sensu" classified as Reddish Oxisol (USDA, 1999; called in Portuguese Latossolo Vermelho - EMBRAPA, 2018). Reddish Oxisol are an advanced state of tempering, deep, of medium texture, moderately to well drained, and considered strongly acidic with low base saturation, while Litholic Neosols have suffered low intensities of pedogenic processes, are shallow and with little organic material and high levels of aluminum and sodium (EMBRAPA, 2018). Both soils were collected at a depth of $40 \mathrm{~cm}$ in Reserva Vellozia. The Litholic Neosol was collected in an environment with native grassland vegetation, whereas the Reddish Oxisol was collected in a fragment with the presence of grasses, trees and shrubs (typical physiognomy environment). The six different treatments employed here are named according to fertilizer dose and/or soil type (details in Table 1).

After collection, the soil of each physiognomy was sieved ( $3 \mathrm{~mm}$ sieve) and divided into three parts (details in Table 1). One portion was stored without receiving any treatment (control treatments for each environment). The second part received an addition of dolomitic limestone with (Total Neutralization Relative Power - TNRT) 100\% until $50 \%$ base saturation, 60 days before planting, according to Martins (2005). The third portion received, in addition to dolomitic limestone, $9 \mathrm{~g} / \mathrm{kg}$ the nutrient NPK (10-10-10), according to instructions of the manufacturer $\left(\right.$ Vitaplan $\left.^{\circledR}\right), 30$ days before planting. The soils were moistened and turned 
three times a week for a complete reaction of the nutrients during the 60 days of preparation (Martins, 2005).

Soil samples $(250 \mathrm{~g})$ from each treatment were packed in plastic bags, identified and sent for analysis of the chemical composition (for details see EMBRAPA, 1997), by Soil Fertility Routine Laboratory at the Federal University of Viçosa. The parameters analyzed were: $\mathrm{pH}(\mathrm{H} 2 \mathrm{O}) \mathrm{N}, \mathrm{P}, \mathrm{K}, \mathrm{Ca}^{2}$, $\mathrm{Mg} 2+, \mathrm{Al}^{3}, \mathrm{H}+\mathrm{Al}, \mathrm{SB}, \mathrm{t}, \mathrm{T}, \mathrm{V}, \mathrm{m}$ and P-Rem (Table 1).

Table 1. Description of the composition and chemical characteristics of the six treatments used to test the survival and growth of seedlings of S. tenerum. Cal = Limestone, $\mathrm{N}=$ Nitrogen $\left(\mathrm{mg} / \mathrm{dm}^{3}\right), \mathrm{P}=$ Phosphorus $\left(\mathrm{mg} / \mathrm{dm}^{3}\right), \mathrm{K}=$ Potassium $\left(\mathrm{mg} / \mathrm{dm}^{3}\right), \mathrm{Ca}^{2}=\mathrm{Calcium}\left(\mathrm{cmolc}_{\mathrm{c}} \mathrm{dm}{ }^{3}\right)$, $\mathrm{Mg}^{2}=$ Effective cation exchange capacity $\left(\mathrm{cmolc} / \mathrm{dm}^{3}\right), \mathrm{H}+\mathrm{AL}=$ Calcium acetate extractor $0.5 \mathrm{~mol} / \mathrm{L}\left(\mathrm{cmolc} / \mathrm{dm}^{3}\right), \mathrm{V}=\mathrm{Base}$ Saturation Index (\%), $\mathrm{m}=$ Aluminum Saturation Index (\%) and P-Rem = Remaining phosphorus (mg/L).

\begin{tabular}{|c|c|c|c|c|c|c|c|c|c|c|c|c|c|c|c|c|}
\hline Treatment & Composition & Codes & $\mathrm{pH}$ & $\mathbf{N}$ & $\mathbf{P}$ & K & $\mathrm{Ca}^{2}$ & $\mathbf{M g}^{2}$ & $\mathrm{Al}^{3}$ & $\mathrm{H}+\mathrm{Al}$ & SB & $\mathbf{t}$ & $\mathrm{T}$ & V & $\mathbf{m}$ & P-Rem \\
\hline $\mathrm{T} 1$ & Reddish Oxisol & Oxisol & 5.02 & 0.094 & 0.2 & 2 & 3.58 & 0.03 & 0.9 & 9.6 & 3.62 & 4.52 & 13.22 & 27.4 & 19.9 & 8.4 \\
\hline $\mathrm{T} 2$ & $\begin{array}{l}\text { Reddish Oxisol } \\
+ \text { limestone } \\
\text { (50\% base } \\
\text { saturation) }\end{array}$ & $\begin{array}{l}\text { Oxisol + } \\
\mathrm{CaCO}_{3}\end{array}$ & 6.72 & 0.179 & 0.6 & 79 & 6.9 & 0.41 & 0 & 1.7 & 7.51 & 7.51 & 9.21 & 81.5 & 0 & 19.9 \\
\hline $\mathrm{T} 3$ & $\begin{array}{l}\text { Reddish Oxisol + } \\
\text { limestone + NPK } \\
(10-10-10)\end{array}$ & $\begin{array}{l}\text { Oxisol + } \\
\mathrm{CaCO}_{3}+ \\
\mathrm{NPK}\end{array}$ & 7.78 & 0.083 & 7 & 172 & 12.19 & 0.32 & 0 & 0.8 & 12.95 & 12.95 & 13.75 & 94.2 & 0 & 18.1 \\
\hline $\mathrm{T} 4$ & Litholic Neosol & Neosol & 7.51 & 0.052 & 2.4 & 19 & 6.81 & 0.12 & 0 & 1.3 & 6.98 & 6.98 & 8.28 & 84.3 & 0 & 41.7 \\
\hline T5 & $\begin{array}{l}\text { Litholic Neosol } \\
+ \text { limestone } \\
\text { (50\% base } \\
\text { saturation) }\end{array}$ & $\begin{array}{l}\text { Neosol } \\
+ \\
\mathrm{CaCO}_{3}\end{array}$ & 8.23 & 0.028 & 1.9 & 16 & 9.23 & 0.15 & 0 & 0.7 & 9.42 & 9.42 & 10.12 & 93.1 & 0 & 36.8 \\
\hline T6 & $\begin{array}{l}\text { Litholic Neosol } \\
+ \text { limestone + } \\
\text { NPK (10-10-10) }\end{array}$ & $\begin{array}{l}\text { Neosol + } \\
\mathrm{CaCO}_{3}+ \\
\mathrm{NPK}\end{array}$ & 8 & 0.036 & 8 & 34 & 10.03 & 0.15 & 0 & 1 & 10.27 & 10.27 & 11.27 & 91.1 & 0 & 40.4 \\
\hline
\end{tabular}

\subsection{Seedling production and planting}

To test the two hypotheses, seedlings were produced from plants (clumps) collected in rupestrian grassland. Each clump was divided into six parts (here on referred to as 'seedlings') (Figure 1). The aerial part of each seedling was pruned to a length of $10 \mathrm{~cm}$. The seedlings were then weighed on a precision scale to obtain initial fresh weight and then placed in trays with water to maintain humidity until planting. The procedure was performed at 7:00h and 10:00h when there is low solar incidence to avoid drying out the roots and to reduce losses during regrowth.

To evaluate the survival and growth of $S$. tenerum in each treatment 300 seedlings were produced from 50 plants in order to maintain a part of each plant (seedling) in one treatment, and thus exclude the influence of a genetic factor in the performance responses of seedlings. Another 200 seedlings were produced to compare the survival rate when grown in a greenhouse to that of direct planting in the field in full sun. In total, 500 seedlings were produced from 84 plants.

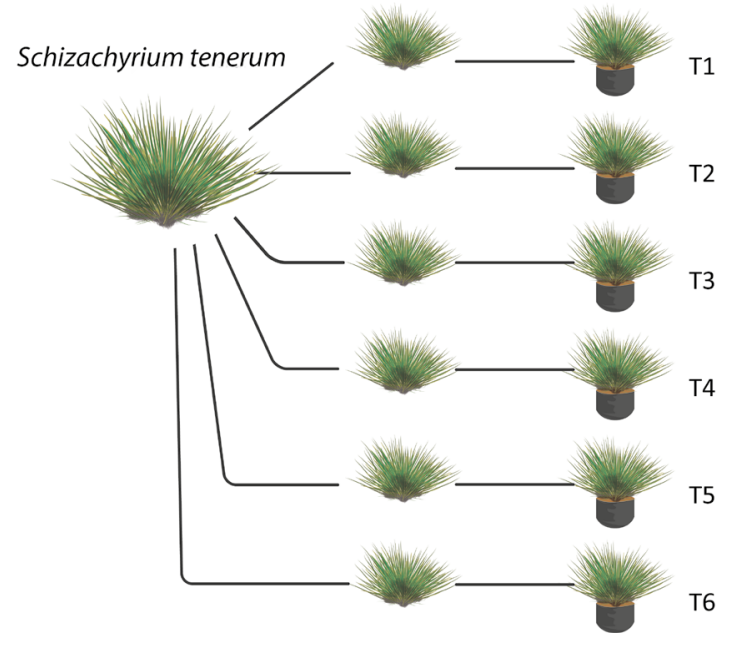

Figure 1. A) Schematic of the collection and preparation of seedlings of the grass $S$. tenerum for planting. One plant (clump) was divided into six parts and each part was planted in one of six different treatments: $\mathrm{T} 1=$ Reddish Oxisol, $\mathrm{T} 2=$ Reddish Oxisol with the addition of limestone, T3= Reddish Oxisol with the addition of limestone and NPK, T4 $=$ Neosol, T5 $=$ Neosol with the addition of limestone, $\mathrm{T} 6=$ Neosol with the addition of limestone and NPK nutrient. 
An experiment was performed in randomized blocks with 50 repetitions in six treatments (total $n=300$ seedlings) to test the hypothesis regarding survival and growth of $S$. tenerum in each treatment. The seedlings were planted in $1 \mathrm{dm}^{3}$ plastic pots. The greenhouse was covered with $50 \%$ shade and was automatically irrigated by sprinkling for five minutes twice a day, morning and afternoon, with an average of $120 \mathrm{ml}$ of water per pot/ day. The experiment was conducted for 120 days from October 2016 to January 2017.

To compare the survival rate of $S$. tenerum in different environmental conditions (greenhouse and field), 100 seedlings were grown in $1 \mathrm{dm}^{3}$ plastic pots containing rupestrian grassland soil (in the greenhouse with the same conditions as before). Another 100 seedlings were planted directly in the field, in part of a cut slope next to the greenhouse. The slope had an inclination of approximately $30^{\circ}$ and was 3 meters high $\times 12$ meters long. It was devoid of vegetation and had compacted soil, with no signs of erosion. Seedlings were distanced from each other by $25 \mathrm{~cm}$. Irrigation was performed manually twice a day, morning and afternoon, with an average of $120 \mathrm{ml}$ of water per hole/day for 120 days from February to May 2017.

\subsection{Collection of data and statistical analysis}

To test the hypothesis regarding survival by treatment, surviving seedlings of $S$. tenerum were counted every 30 days for 120 days. A survival analysis was performed to evaluate differences in survival among the six treatments. The survival analysis consisted of assessing the life span of each seedling per treatment from the beginning of the study to the final moment (with the occurrence of death) (Pinder et al., 1978).

A correlation analysis was performed to assess the association between seedling survival and chemical characteristics of the soil. This analysis tests whether the investigated variables are correlated, with values above 0 and up to 1 indicating a positive correlation, that is, variable $y$ increases together with variable $\mathrm{x}$. On the other hand, values between -1 and below 0 indicate an inverse correlation, that is, variable y decreases with increases in variable $\mathrm{x}$ (Callegari-Jaques, 2003).

To evaluate the growth of seedlings in each treatment, shoot length was measured with a graduated ruler $(\mathrm{cm})$, and the number of tillers counted. At the end of 120 days, the surviving seedlings were submitted to destructive collection. This involved carefully washing the seedlings under running water and wrapping them in paper towels to remove excess moisture. Total length $(\mathrm{cm})$ and weight (precision scale) of the root and the aerial pert were subsequently measured to obtain wet weight $(\mathrm{g})$. Each individual was packed separately in paper bags and dried in an oven at $70^{\circ}$ until constant weight (approximately seven days), after which they were weighed again to obtain final dry weight.

These measurements were then used to calculate the root/shoot ratio according to McGraw and Garbutt (1990). Generalized linear models (GLMs) were constructed to test the effect of treatments on growth with treatment as the predictor variable and total length $(\mathrm{cm})$, tiller number, biomass $(\mathrm{g})$ and root/aerial part ratio as response variables. The error distribution of each model was tested and found adequate for each variable according to the analysis of the model (Crawley, 2007).

To compare the survival of seedlings grown in the greenhouse versus in full sun, the percentage of surviving seedlings in each environment was calculated monthly for 120 days. To test this difference, a GLM was built after verifying homogeneity of variances of the data. Percentage survival was used as the response variable while environment (greenhouse of full sun) was the predictor variable.

All analyses were performed with the aid of the program R (R Development Core Team, 2010). Results that showed differences between response variables were submitted to post hoc contrast analysis at $5 \%$ significance level.

\section{RESULTS}

Survival of the seedlings of $S$. tenerum $(\mathrm{p}<0.001)$ (Figure 2) decreased markedly in different treatments after 30 days of the experiment. The average survival of plants at the end of 120 days was higher in Reddish Oxisol (T1) and Reddish Oxisol $+\mathrm{CaCO}_{3}$ (T2) with $66 \%$ and $70 \%$, respectively (Table 2 ). These two treatments had a higher concentration of nitrogen, a lower concentration of phosphorus and a more acidic $\mathrm{pH}$ (Table 1). Seedlings grown in RGS (T4) had lower survival, with at least 50\% of seedlings dying before 90 days (Figure 2).

Strong associations were found between survival rate of the seedlings and the concentration of nitrogen, phosphorus, and $\mathrm{pH}$ value of treatments. The average survival of seedlings was increased in treatments with a higher amounts of nitrogen $(r=0.79 ; p<0.05)$, while it was decreased with greater presence of phosphorus and basic $\mathrm{pH}(\mathrm{r}=-0.85 ; \mathrm{p}<0.001$ and $\mathrm{r}=-0.77 ; \mathrm{p}<0.05$, respectively). Average survival was lower for higher concentrations of phosphorus and elevated $\mathrm{pH}$. 
Table 2. Mean and standard error of growth parameters for seedlings of $S$. tenerum cultivated in different substrate treatments.

\begin{tabular}{lcccccc} 
& T1 & T2 & T3 & T4 & T5 & T6 \\
\hline Survival (\%) & $66 \pm 6.76$ & $70 \pm 6.54$ & $42 \pm 7.05$ & $44 \pm 7.09$ & $40 \pm 6.99$ & $30 \pm 6.54$ \\
\hline Total length (cm) & $77.35 \pm 4.16$ & $68.15 \pm 3.26$ & $56.10 \pm 5.08$ & $53.16 \pm 4.63$ & $43.50 \pm 3.52$ & $50.90 \pm 4.98$ \\
\hline Number of tillers (unit) & $7.18 \pm 1.00$ & $6.42 \pm 0.61$ & $3.45 \pm 0.69$ & $4.00 \pm 0.52$ & $3.52 \pm 0.59$ & $3.73 \pm 0.56$ \\
\hline Root/aerial part ratio & $2.69 \pm 0.47$ & $1.97 \pm 0.36$ & $2.08 \pm 0.34$ & $1.71 \pm 0.36$ & $2.67 \pm 1.09$ & $1.351 \pm 0.22$ \\
\hline We weight (g) & $8.60 \pm 1.10$ & $6.13 \pm 0.76$ & $4.60 \pm 0.80$ & $5.36 \pm 0.69$ & $3.81 \pm 0.86$ & $4.90 \pm 0.78$ \\
\hline
\end{tabular}

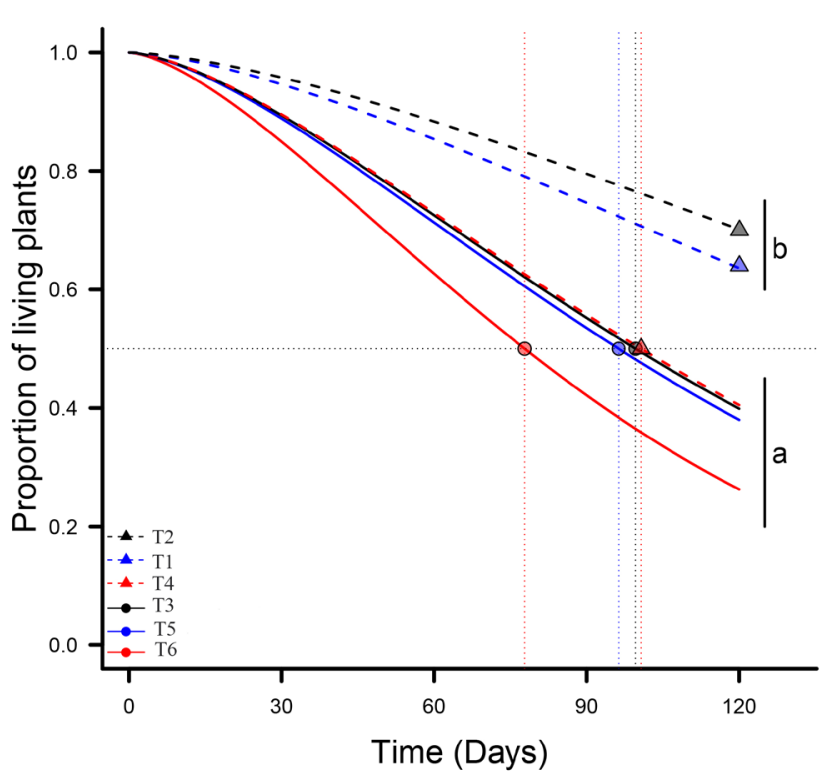

Figure 2. Survival of seedlings of $S$. tenerum grown on different substrates over 120 days: $\mathrm{T} 1=$ Reddish Oxisol T2= Reddish Oxisol with the addition of limestone, T3= Reddish Oxisol soil with the addition of limestone and NPK, T4= Litholic Neosol, T5= Litholic Neosol with the addition of limestone, T6 = Litholic Neosol with the addition of limestone and NPK nutrient. Dashed vertical line indicate the time when mortality reached $50 \%$.

Seedlings of S. tenerum grown in $\mathrm{T} 1$ and $\mathrm{T} 2 \mathrm{had}$ higher average total lengths $(\mathrm{F}=8.818 ; d f=139 ; \mathrm{p}<0.001)$ and a greater number of tillers $(\mathrm{F}=4.784 ; d f=135 ; \mathrm{p}<0.001)$ than the other treatments (Figure 3, Table 2). Seedlings grown in $\mathrm{T} 1$ and $\mathrm{T} 2$ produced $80 \%$ and $60 \%$, respectively, more tillers than seedlings grown in the other treatments (Figure 3, Table 2). Plant wet weight $(\mathrm{F}=3.794 ; d f=139 ; \mathrm{p}<0.001)$ was $40 \%$ higher for seedlings grown in $\mathrm{T} 1$ compared to the other treatments (Figure 3). All seedlings allocated more biomass to the root than to the aerial part (Figure 3, Table 2), while the root/aerial part ratio did not vary among treatments $(\mathrm{F}=0.910 ; d f=139 ; \mathrm{p}=0.473)$.

Survival of seedlings grown in a greenhouse after 120 days was $62 \%$, while those grown in the field reached only $26 \%(d f=247,42 ; \mathrm{p}<0.001)$ (Figure 4).
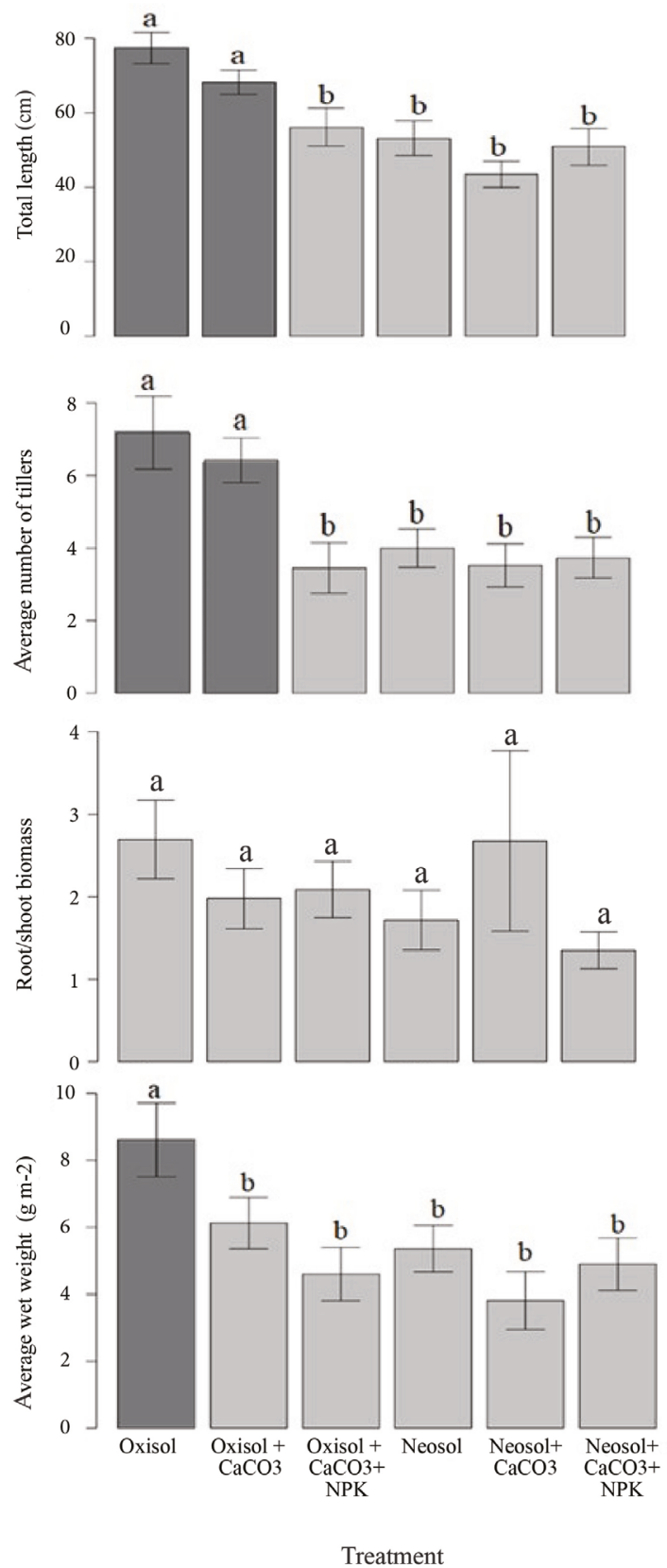

Figure 3. Effect of treatments on the growth of seedlings of $S$. tenerum produced by vegetative propagation. Means followed by the same letters do not differ significantly at $5 \%$ probability. 


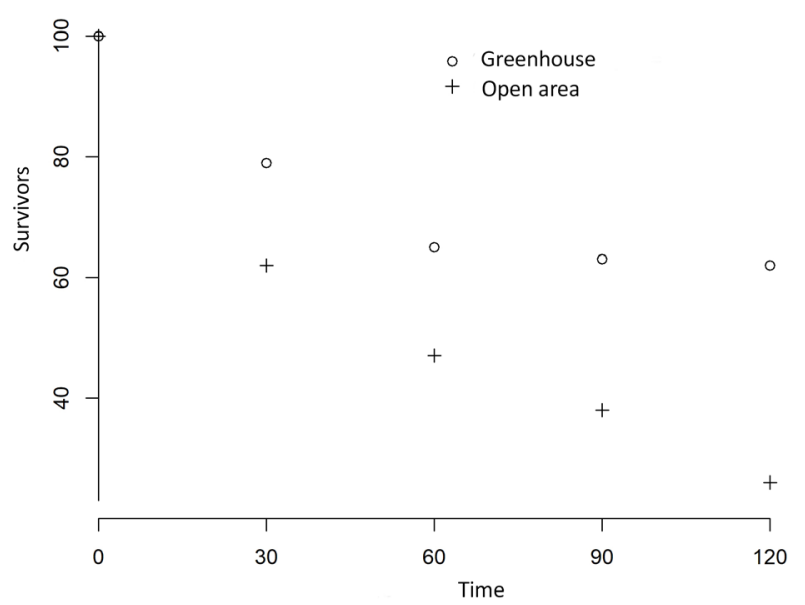

Figure 4. Survival percentage for seedlings of S. tenerum when grown in a greenhouse or in full sun for 120 days.

\section{DISCUSSION}

As predicted by hypothesis I, seedlings grown in more fertile soils showed a higher survival rate and greater growth in treatments with Reddish Oxisol ( $\mathrm{T} 1$ and T2). These treatments had in common the highest concentrations of nitrogen and slightly acidic $\mathrm{pH}$ (below 7) in common. Nitrogen is considered one of the main macronutrients absorbed by plants, being responsible for the synthesis of protein and organic compounds (Lemaire et al., 2011).

Phosphorus, which is an important nutrient for seedling development, showed an inverse correlation with survival, being present in higher doses in treatments where seedlings survived less. In this sense, it is believed that the presence of arbuscular mycorrhizal fungi (AMF), very common in "Cerrado" and rupestrian grassland and important for plants, may have been reduced in the medium rich in phosphorus (Moreira et al., 2019; Tang et al., 2001). The role of mycorrhizal fungi in the development of native plants of the "Cerrado" has been the target of investigation and is considered responsible for the greater development of seedlings even in soil that is poor in nutrients (Martins et al., 1999). Rupestrian grassland possess a great diversity of AMF, with 51 species inventoried in the Serra do Cipó alone (Coutinho et al., 2015), and plants developed in these environments may have strong dependence on mycorrhiza.

Although plants showed better development in more fertile soils, we also expected the addition of NPK and the improvement these nutrients to increase seedling survival, but the opposite occurred. Substrates that were not fertilized with these nutrients had the highest concentrations of $\mathrm{N}$, contrary to what we expected. Thus, from the point of view of producing seedlings for planting in degraded areas, this result is quite beneficial as it reduces production costs, which is a decisive factor for using the method. Other studies with native grasses have also found high survival and growth rates for plants grown in "Cerrado" soil without fertilization. Oliveira (2019) evaluated the survival of seedlings of the native grass Schizachyrium sanguineum and observed almost total survival (98\%) of seedlings cultivated in "Cerrado" soil, and the number and height of tillers were twice that for plants grown in fertilized non-commercial soil. The species Axonopus laxiflorus and Sporobolus metallicolus showed $100 \%$ chance of survival and high growth rates when grown in lateritic soil in rupestrian grassland (Figueiredo et al., 2018). Tilman and Wedin (1991) studied five species of grasses (Agrostis scabra, Agropyron repens, Poa pratensis, Schizachyrium scorparium, Andropogon Gerardi) in an experimental nitrogen fertilization gradient and found indications of maximum survival of all species in different cultivation conditions.

Biomass allocation was higher in roots than in the aerial part in all treatments of the present study, which is a characteristic of great interest for planting in restoration areas. The elongation of roots promotes greater aggregation of soil and better captures limiting resources, such as water and nutrients, for the maintenance and development of plants in normally stressful environmental conditions. In fact, plants grown in soils with low nutrient contents allocate more energy to the roots in order to increase the capacity to absorb scarce resources (Chapin III, 1980; Mašková \& Herben, 2018). On the other hand, in nutritious medium, plants invest in aerial parts, thus optimizing photosynthesis and plant development above ground (Chapin III, 1980; Müller et al., 2000; Negreiros et al., 2014a; Yan et al., 2016).

As predicted by hypothesis II, survival of seedlings of S. tenerum was three times higher in the greenhouse than in full sun. This difference may be related to the controlled conditions of the greenhouse where there is less temperature fluctuation and less sun exposure for the seedlings. This is in contrast to the rupestrian grassland environment of the present study, where conditions are normally extreme with regard to temperature, humidity and solar incidence (Negreiros et al., 2014b), which increases stress for seedlings. In addition, the soil of the slope where the planting was performed was compacted and, thus, may have impaired the development of roots (Perez, 2008). A similar result was obtained by Oliveira (2014) in a study on the survival of tree species seedlings grown in a greenhouse with different levels of shading, with three-times greater survival with shading of 50\% compared to the open environment. The species Schizolobium amazonicum also showed greater survival in a greenhouse compared to cultivation in full sun (Frigotto et al., 2015). The high mortality of seedlings planted in a degraded area 
indicates the need for a period in the greenhouse to recover from water stress after production.

The high rates of survival and development of seedlings of $S$. tenerum in Reddish Oxisol demonstrate the feasibility of using the technique of vegetative propagation through clump division. In addition, it is important to test how and when seedlings grown in a greenhouse can be taken for planting since direct field cultivation has had little success. Nevertheless, this result is promising for the technique to be expanded on a large scale for use in restoration due to its simplicity and low cost. New studies with different types of soil, nutritional concentrations and grass species will be important to expand knowledge and improve the technique.

\section{ACKNOWLEDGEMENTS}

The authors thank two anonymous reviewers for their contributions. We also thank Capes, CNPQ, Fapemig, Vale for financial support and Reserva Vellozia for logistical support. We Thank Jéssica Silveira, Cecília Loureiro and Bárbara Rúbia for their assistance in the field work, Yumi Oki for correcting the manuscript and Carlos Schaefer for his support in soil classification.

\section{SUBMISSION STATUS}

Received: 27 Jun. 2020.

Accepted: 16 Nov. 2020.

\section{CORRESPONDENCE TO}

\section{Letícia Sena}

Universidade Estadual de Montes Claros, Centro de Ciências Biológicas e da Saúde, Av. Prof. Rui Braga, s/n, CEP 39401-089 Montes Claros, MG, Brasil.

e-mail: leticiacsena@yahoo.com.br

\section{REFERENCES}

Almeida HA, Bahia TO, Gélvez-Zúñiga I, Fernandes GW. Together yet separate: variation in soil chemistry determines differences in the arboreal-shrub structure of two contiguous rupestrian environments. Acta Botanica Brasilica 2018; 32:578-587.

Barbosa NPU, Fernandes GW, Carneiro MAA, Júnior LAC. Distribution of non-native invasive species and soil properties in proximity to paved roads and unpaved roads in a quartzitic mountainous grassland of southeastern Brazil (rupestrian fields). Biological Invasions 2010; 12:3745-3755.

Boldrini II, Miotto STS, Longhi-Wagner HM, Pillar VP, Marzall $\mathrm{K}$. Aspectos florísticos e ecológicos da vegetação campestre do Morro da Polícia, Porto Alegre, RS, Brasil. Acta Botanica Brasilica 1998; 12: 89-100.

Callegari-Jaques SM. Bioestatística: princípios básicos e aplicações. Porto Alegre. Artmed Editora AS; 2003.
Carmona R, Martins CR, Fávero AP. Características de sementes de gramíneas nativas do cerrado. Pesquisa Agropecuária Brasileira 1999; 34:1066-1074.

Cava MGDB, Isernhagen I, Mendonça AHD, Durigan G. Comparing techniques to restore the woody cerrado vegetation in abandoned pastures. Hoehnea 2016; 43:301-315.

Chapin III FS. The mineral nutrition of wild plants. Annual Review of Ecology and Systematics 1980; 11: 233-260.

Coutinho ES, Fernandes GW, Berbara RLL. Variation of arbuscular mycorrhizal fungal communities along an altitudinal gradient in rupestrian grasslands in Brazil. Mycorrhiza 2015; 25:627-638.

Crawley MJ. The R Book. New York: John Wiley and Sons; 2013.

Durigan G, Ivanauskas NM, Zakia MJB, Abreu RCR. Control of Invasive plants: ecological and socioeconomic criteria for the decision making process. Natureza \& Conservação 2013; 11: 23-30.

Empresa Brasileira de Pesquisa Agropecuária- EMBRAPA. Centro Nacional de Pesquisa de Solos. Manual de métodos de análise de solo. 2nd ed. Rio de Janeiro. EMBRAPA; 1997.

Empresa Brasileira de Pesquisa Agropecuária - EMBRAPA. Sistema brasileiro de classificação de solos. 5.ed. Brasília, EMBRAPA, 356p. 2018.

Fernandes GW, Barbosa NPU. Bombas relógio que ameaçam a natureza em Minas Gerais. Scientific American Brasil 2013; 135:60-61.

Fernandes GW, Coelho MS, Machado RB, Ferreira ME, Aguiar LDS, Dirzo R, Scariot A, Lopes CR. Afforestation of savannas: an impending ecological disaster. Natureza \& Conservação 2016a; 14:146-151.

Fernandes GW, Toma TSP, Angrisano P. Overbeck G. Challenges in the restoration of quartzitic and ferruginous rupestrian grasslands. In: Fernandes GW (ed) Ecology and Conservation of Mountaintop Grasslands in Brazil. Springer International Publishing Switzerland, pp 449-478. 2016b.

Figueiredo MA, Baêta HE, Kozovits AR. Germination of native grasses with potential application in the recovery of degraded areas in Quadrilátero Ferrífero, Brazil. Biota Neotropical 2012; 12:118-123.

Figueiredo MA, Diniz AP, Messias MCTB, Kozovits AR. Propagation and establishment of rupestrian grassland grasses for restoration of degraded areas by mining. Brazilian Journal of Botany 2018; 41:287-295.

Frigotto T, Brun EJ, Mezzalira CC, Navrski MC, Biz S, Ribeiro RR. Desenvolvimento de mudas de Schizolobium amazonicum Huber ex Ducke em diferentes ambientes em viveiro. ENFLO 2015; 3:9-17.

Giuliette AM, Pirani JR, Harley RM. Espinhaço range region. Eastern Brazil. In: Davis SD, Heywood VH, Herrera-MacBryde O, Villa-Lobos J, Hamilton AC (eds) Centres of plant diversity. A guide and strategies for the conservation. IUCN Publications Unit, Cambridge 1997; pp 397-404.

Guimarães AJM, Araújo GM, Corrêa GF. Estrutura fitossociológica em área natural e antropizada de uma vereda em Uberlândia, MG. Acta Botanica Brasilica 2002; 16:317-329.

Haridasan M, Pinheiro AAMC, Torres FRR. Resposta de algumas espécies do estrato rasteiro de um cerrado à calagem e à adubação. In: Leite LL, Saito CH (eds) Contribuição ao conhecimento ecológico do cerrado. Brasília. Universidade de Brasília. 1997.

Haridasan M. Nutrição mineral de plantas nativas do cerrado. Revista Brasileira de Fisiologia Vegetal 2000; 12:54-64. 
Jacobi CM, Carmo FF, Vincent RC. Estudo fitossociológico de uma comunidade vegetal sobre canga como subsídio para a reabilitação de áreas mineradas no Quadrilátero Ferrífero, MG. Revista Árvore 2008; 32:345-353.

Klink CA, Machado RB. Conservation of the Brazilian cerrado. Conservation Biology 2005; 19:707-713.

Lemaire G, Hodgson J, Chabbi A. Grassland productivity and ecosystem services. London. British Library; 2011.

Le Stradic S, Buisson E, Fernandes GW. Vegetation composition and structure of some Neotropical mountain grasslands in Brazil. Journal of Mountain Science 2015a; 12:864-877.

Le Stradic S, Silveira FAO, Buisson E, Cazelles K, Carvalho V, Fernandes GW. Diversity of germination strategies and seed dormancy in herbaceous species of rupestrian grassland grasslands. Austral Ecology 2015b; 40:537-546

Martins CR, Miranda JCC, Miranda LN. Contribuição de fungos micorrízicos arbusculares nativos no estabelecimento de Aristida setifolia Kunth em áreas degradadas do cerrado. Pesquisa Agropecuária Brasileira 1999; 34:665-674.

Martins CE. Práticas agrícolas relacionadas à calagem do solo. EMBRAPA. Juiz de Fora. Comunicado Técnico. 2005.

Martins CR, Hay JDV, Valls JF, Leite LL, Henriques RPB. Levantamento das gramíneas exóticas do Parque Nacional de Brasília, Distrito Federal, Brasil. Natureza \& Conservação 2007; 5:23-30.

Mašková T, Herben T. Root:shoot ratio in developing seedlings: how seedlings change their allocation in response to seed mass and ambient nutrient supply. Ecology and Evolution 2018; 8:7143-7150.

McGraw JB, Garbutt K. Demographic growth analysis. Ecology 1990; 71:1199-1204.

Mendonça RC, Felfili JM, Walter BMT, Silva Júnior MC, Rezende AV, Filgueiras T.S, Nogueira PE, Fagg CW. Flora vascular do bioma cerrado: checklist com 12.356 espécies. In: Sano SM, Almeida SP, Ribeiro JF (eds) Cerrado Ecologia e Flora. Brasília. Embrapa. Pp; 422-442. 2008.

Messias MCTB, Leite MGP, Neto M, Alves JA, Kozovits AR. Fitossociologia de campos rupestres quartzíticos e ferruginosos no Quadrilátero Ferrífero, Minas Gerais. Acta Botanica Brasilica 2012; 26:230-242.

Messias MCTB, Leite MGP, Meira-Neto JAA, Kozovits AR, Tavares R. Soil vegetation relationship in quartzitic and ferruginous Brazilian rocky outcrops. Folia Geobotanica 2013; 48:509-521.

Moreira SD, França AC, Grazziotti PH, Leal FDS, Silva EDB. Arbuscular mycorrhizal fungi and phosphorus doses on coffee growth under a non-sterile soil. Revista Caatinga 2019; 32:72-80.

Müller I, Schmid B, Weiner J. The effect of nutrient availability on biomass allocation patterns in 27 species of herbaceous plants. Perspective in Plant Ecology Evolution and Systematics 2000; 3:115-127.

Negreiros D, Esteves D, Fernandes GW, Berbara RL, Oki Y, Vichiato M, Chalub C. Growth survival trade off in the widespread tropical shrub Baccharis dracunculifolia (Asteraceae) in response to a nutrient gradient. Tropical Ecology 2014a; 55:167-176.

Negreiros D, Le Stradic S, Fernandes GW, Rennó HC. CSR analysis of plant functional types in highly diverse tropical grasslands of harsh environments. Plant Ecology 2014b; 215: 379-388

Oliveira LMB. Sobrevivência e crescimento de mudas resgatadas em função do tempo de transplantio e níveis de sombreamento. [dissertação]. Diamantina. Universidade Federal dos Vales do Jequitinhonha e Mucuri; 2014.

Oliveira ACC. Produção de mudas de duas espécies de gramíneas nativas para restauração do cerrado. [dissertação]. São Paulo. Universidade Federal de São Carlos; 2019.

Overbeck GE, Hermann JM, Andrade BO, Boldrini II, Kiehl K, Kirmer A, Koch C, Kollmann J, Meyer ST, Müller SC, Nabinger C, Pilger GE, Trindade JPP, Vélez-Martin E, Walker EA, Zimmermann DG, Pillar VD. Restoration ecology in Brazil time to step out of the forest. Natureza \& Conservação 2013; 11:92-95.

Perez NB. Multiplicação vegetativa de plantas forrageiras recomendações para plantio. Bagé. Embrapa Pecuária Sul; 2008.

Pinder III JE, Wiener JG, Smith MH. The Weibull distribution: a new method of summarizing survivorship data. Ecology 1978; 59:175-179.

R Development Core Team: R: A language and environment for statistical computing. Computer programme http://www.R-project.org/. 2010.

Santos AGD. Propagação de Axonopus parodii, Paspalum notatum e Paspalum lepton para cultivo de gramados. [dissertação]. Pernambuco. Universidade Federal Rural de Recife; 2017.

Simberloff D. How much information on population biology is needed to manage introduced species? Conservation Biology 2003; 17:83-92.

Tang F, White JA, Charvat I. The effect of phosphorus availability on arbuscular mycorrhizal colonization of Typha angustifolia. Mycologia 2001; 93:1042-1047.

Teixeira WA, Lemos Filho JP. A flórula rupestre do Pico de Itabirito, Minas Gerais, Brasil: lista das plantas vasculares. Boletim de Botânica 2013; 31:199-230.

Tilman D, Wedin D. Plant traits and resource reduction for five grasses growing on a nitrogen gradient. Ecology 1991; 72:685-700.

United States Department of Agriculture (USDA). Soil taxonomy a basic system of soil classification for making and interpreting soil surveys. Agriculture Handbook number Washington, USA. 871p. 1999.

Viana PL, Lombardi JA. Florística e caracterização dos campos rupestres sobre canga na Serra da Calçada, Minas Gerais, Brasil. Rodriguésia 2007; 58:159-177.

Viana PL, Filgueiras TS. Inventário e distribuição geográfica das gramíneas (Poaceae) na Cadeia do Espinhaço, Brasil. Megadiversidade 2008; 4:71-88.

Yan B, Ji Z, Fan B, Wang X, He G, Shi L, Liu G. Plants adapted to nutrient limitation allocate less biomass into stems in an arid-hot grassland. New Phytologist 2016; 211:1232-1240. 